UDC 336.226.44:338:504.06 [338.242:658.265(477)] doi: 10.12958/1817-3772-2020-4(62)-64-69

V. Ostrovetskyy,

ORCID 0000-0003-3985-5236,

e-mail: v.ostrovetskyy@gmail.com,

Academy of Financial Management, Kyiv

\title{
PERSPECTIVES FOR THE DEVELOPMENT OF THE ENVIRONMENTAL TAXATION SYSTEM: CONSOLIDATION, DIFFERENTIATION, EXPANSION OF THE TAX BASE
}

Introduction. The challenges of time require the search for new ways to solve the main task of the economy, which is to meet the unlimited and ever-growing needs of society in the face of physical limitations and exhaustion of the resource base. The problem is undergoing permanent transformations as a result of the development of scientific and technological progress, accompanied by the deterioration of the environmental situation due to air pollution, water, land resources, etc., as well as the depletion of non-renewable factors of natural origin.

One of such promising areas is the concept of "green" economy, based on the concept of "green" growth, i.e. stimulating sustainable development of the economic system based on the rational use of natural resources, ensuring their protection, restoration and preservation for future generations. The state should play a key role in achieving this goal. The solution of these tasks requires the development of a new strategy for the development of the economic system using effective and manageable levers of state regulation, budget and tax in particular.

Problems in the field of environment and ecology, their solution is the key to ensuring sustainable development of the economic system. The population of Planet Earth today is 7 billion people. Over the past 50 years, the population of Planet Earth has tripled. The vast majority (over 60\%) live in cities, which are the main source of environmental pollution due to the saturation of industrial production, which generates harmful substances that are released into the air and water bodies. Also, people's lives are accompanied by the accumulation of household waste that needs to be disposed of and recycled. Thus, over the past 10 years, production volumes using nitrogen, phosphate and potassium fertilizers have increased 12 times, and primary energy consumption (electricity and heat). Energy production is associated with the conversion of energy resources of any origin (oil, coal) into thermal energy using special technical means that do not always meet environmental standards for emissions of pollutants into the air and water.

According to experts, by 2050 the world's population will increase by at least a third. Accordingly, we should expect an increase in demand for water and energy consumption, heat in particular. Accordingly, we should expect an increase in the burden on the ecologi- cal system, its transformation, deterioration of the ecological situation, reduction of biodiversity, and even the extinction of certain species of animals and plants.

Analysis of recent research. The issues of payment for the use of natural resources, in particular, environmental taxes, identification, identification and classification of users and intensification of rational use of natural resources, the impact of environmental taxation on the environment, its structure and parameters are disclosed in G. Bell, O. H. Brownlee, R. E. Wagner, P. Richardson, A. Pigou and other classics of economic theory. A significant contribution to the study of environmental issues was made by prominent scientists M. I. Bublik, B. M. Danylyshyn, V. S Mishchenko, S. V. Mochernyi, M. A. Hvesyk and others.

However, the unsatisfactory state of technogenic and ecological situation in Ukraine, which slows down the development of Ukraine's economic system, as well as the current economic situation in Ukraine due to the political crisis in eastern Ukraine determine the relevance of further research aimed at improving Ukraine's taxation in general and in the direction of its greening, including.

Examining the issues of stimulating sustainable development based on improving the use of nature, many researchers agree that among the main methods of administrative and market regulation of economic processes on an investment-innovation basis (development of regions in decentralization of public administration in Ukraine) include environmental taxes, payments for environmental pollution, payment for the use of environmental services, as an effective tool to stimulate the reduction of harmful emissions and focus on their environmental purpose [1-11].

Relevance and purpose. Ukraine's economic system needs structural changes in industrial production, including through the intensification of the introduction and use of low-waste technologies, as well as energy conservation and rational use of Ukraine's natural resource potential. "Green" growth should be one of the catalysts for intensification of investment activity in Ukraine and the introduction of innovative production technologies that will stimulate sustainable and stable development of Ukraine's economic system and the creation of new economic opportunities. In this context, the intensification of the use of all opportunities of the state to stimulate "green" growth, in particular, on the basis 
of intensifying the use of tax instruments, including taxation of production and consumption of environmentally harmful goods, as well as expanding the responsibility of producers whose economic activities adversely affect the environment and public health. This allows us to formulate the purpose of the article, which is to study the prospects for the development of environmental taxation in the direction of creating organizational and legal conditions for intensifying the development of the concept of "green" growth in Ukraine.

Summary of the main material Environmental taxes are implemented and managed in order to create organizational and economic forms of management of environmentally hazardous activities of economic entities. The first attempts to introduce environmental taxation were observed at the beginning of the last century. Thus, Arthur Pigou noted that the manufacturer pollutes the environment as a result of efforts to maximize its profits. In this case, such an enterprise is not harmed by such activities. Pollution costs are transferred to other economic agents and society as a whole, which, at the physical level, is manifested through deteriorating living conditions, increased risks of disease and premature mortality, reduced productivity, etc. [12, p. 26].

In the 90 s of the twentieth century. environmental tax reforms have begun in some highly developed European countries. Among the reasons for the slowdown in this area are the need to maintain free competition in industrial production and avoid excessive tax burden on energy-dependent sectors of the economy. At the beginning of the XXI century. In connection with the actualization of anti-carbon policy, the need for environmental tax reform was highlighted among the priorities of current economic policy, as taxation of the results of natural resources remains an incentive to ensure their rational use and reduce pollutant emissions into the environment (water, air etc.).

The slowdown in economic growth since the global economic crisis of 2008-2009, accompanied by political instability in the East in Ukraine, complicates the state's task of reducing poverty, developing health care, education and other social components, and identifying sufficient financial resources for public capital investments. The global debt crisis and the COVID-19 pandemic in 2020 have further complicated the functioning of the global economic system. Jurisdictions with low per capita incomes and underdeveloped industrial production are particularly affected.

These negative trends have led to a change in the development of the global economic system. The virtual sector of the economy is growing faster. There is an active development of the IT sector, the debt instruments market, as well as the services sector. Accordingly, there is a retraining and transfer of qualified personnel to other economic activities due to the reduction of production, military-political conflicts, the environmental situation in particular. Such negative trends require authorized persons to develop and implement effective measures to stabilize the situation, including in the direction of welfare, development of high-tech industries based on reducing energy intensity of production and GDP, as well as reducing harmful emissions per unit of output.

The main task in developing the organizational and legal conditions for stimulating "green" growth is the rational transformation of natural resources into other forms of capital. The main activities to address this problem should be to increase labour productivity and competitiveness of Ukraine's economic system, taking into account the financing of national security, education and infrastructure development, promoting employment without harming the environment and its preservation for future generations.

Since the beginning of the third millennium, there has been GDP growth in almost all countries of the world, but in different amounts. The structure of world GDP in terms of regions and types of economic activity according to the World Bank are presented in Table 1.

The structure of world GDP in terms of regions and types of economic activity

Table 1 according to the World Bank

\begin{tabular}{|c|c|c|c|c|c|c|c|c|c|c|}
\hline & \multirow{2}{*}{\multicolumn{2}{|c|}{$\begin{array}{c}\text { GDP } \\
\text { \$ billions }\end{array}$}} & \multicolumn{2}{|c|}{ Agriculture } & \multicolumn{2}{|c|}{ Industry } & \multicolumn{2}{|c|}{$\begin{array}{c}\text { Manufac- } \\
\text { turing }\end{array}$} & \multicolumn{2}{|c|}{ Services } \\
\hline & & & \multicolumn{8}{|c|}{$\%$ of GDP } \\
\hline & 2010 & 2019 & 2010 & 2019 & 2010 & 2019 & 2010 & 2019 & 2010 & 2019 \\
\hline Ukraine & 136.0 & 153.8 & 7 & 9 & 26 & 23 & 13 & 11 & 55.1 & 54.4 \\
\hline World & $66,113.1$ & $87,697.5$ & 4 & 4 & 27 & 28 & 16 & 17 & 63.2 & 61.2 \\
\hline East Asia \& Pacific & $16,988.6$ & $26,979.8$ & 6 & 4 & 36 & 34 & 24 & 23 & 57.0 & 60.5 \\
\hline Europe \& Central Asia & $20,959.2$ & $22,748.8$ & 2 & 2 & 24 & 23 & 14 & 14 & 64.1 & 64.7 \\
\hline Latin America \& Caribbean & $5,348.2$ & $5,719.3$ & 5 & 5 & 29 & 23 & 14 & 12 & 55.8 & 60.6 \\
\hline Middle East \& North Africa & $2,766.8$ & $3,701.4$ & 5 & 4 & 46 & 42 & 14 & 14 & 47.2 & 51.2 \\
\hline North America & $16,611.3$ & $23,117.8$ & 1 & 1 & 20 & 18 & 12 & 11 & 75.2 & 77.4 \\
\hline South Asia & $2,060.8$ & $3,598.0$ & 18 & 16 & 29 & 25 & 16 & 14 & 46.6 & 50.7 \\
\hline Sub-Saharan Africa & $1,380.7$ & $1,755.0$ & 17 & 15 & 28 & 27 & 10 & 11 & 50.4 & 50.9 \\
\hline
\end{tabular}

Source: World Bank. 2020. Available to: http://wdi.worldbank.org/table/4.2. 
According to the UN, the "green" economy is based on reducing carbon emissions, improving the efficiency of all types of resources, as well as forming a system of compliance with the interests of society as a whole [13], which provides environmentally sustainable economic development based on improving the quality of life. Many international experts believe that the "green" economy helps to improve the quality of life, reduce social inequality, reduce environmental risks, in particular, prevent the depletion of natural resources, promote their restoration and preservation for future generations.

At the national level, the "green" economy and "sustainable development" are considered as defining principles in the main strategic and policy documents that determine the basis for the development of national economic systems. And compliance with the principles of "green" economy is determined by an important component of international cooperation in all types of economic activity [14-18].

However, in the vast majority of cases, the use of economic instruments, environmental taxes in particular does not have a proper impact on the intensity and level of carbon emissions (in relation to GDP). There is a discrepancy between the parameters of environmental taxation and the amount of damage to the environment, including in terms of financial support for the costs of its preservation and restoration. A small part of the funds accumulated in the budget system from the collection of environmental taxes is used for environmental purposes.

In theory, it is noted that the economic instruments of environmental policy (primarily, such as environ- mental taxes and fees) are designed to stimulate the reorientation of producers (consumers) to production (consumption) for less harmful goods. This will contribute to the expansion of waste recycling based on the introduction in Ukraine of taxes (fees) on environmentally harmful products, taking into account the investment criterion (normalization of operating, investment and other costs). At the same time, there are such groups of goods as packaging, electrical and electronic equipment, tires, oils, etc., which as a result of wear and loss of consumer properties are converted into waste [19].

In order to reduce emissions, discharges and waste generation, or the impact of physical and biological factors on recipients, some authors justify the introduction of technogenic insurance and recycling fees [20]. Others, linking the improvement of environmental taxation with the strengthening of investment potential for the reproduction of natural resources, propose to increase the rates of environmental taxes and penalties for pollutant discharges, to introduce special coefficients of regulation of existing regulations [21].

Environmental taxes perform two main tasks: replenishment of the state treasury (mobilization of budget revenues) and ensuring the protection and reproduction of natural resource potential, based on the targeted use of funds accumulated in the budget system to finance state environmental programs.

In the scientific literature on taxation, common features and differences between taxes and usage fees are considered. A comparison of individual characteristics of the tax and usage fee, which is proposed by the authors of this publication, is presented in Table 2 .

Comparison of individual characteristics of the tax and usage fees

Table 2

\begin{tabular}{|c|c|c|}
\hline Specifications & Tax & Usage fee \\
\hline 1 & 2 & 3 \\
\hline Formation & $\begin{array}{l}\text { Occurs as a result of economic } \\
\text { activity in a particular jurisdic- } \\
\text { tion }\end{array}$ & $\begin{array}{l}\text { Voluntary and mandatory. Collected as a result of the use of spe- } \\
\text { cific goods (services), arises in the case of a certain type of activ- } \\
\text { ity (payment for public services (state duty, patenting, issuance } \\
\text { of special certificates, etc.), the use of natural resources }\end{array}$ \\
\hline $\begin{array}{l}\text { The purpose of } \\
\text { implementation }\end{array}$ & $\begin{array}{l}\text { Mobilization of state budget } \\
\text { revenues }\end{array}$ & $\begin{array}{l}\text { Rational distribution between competing entities based on the es- } \\
\text { tablishment of value and special conditions of access to the use } \\
\text { of certain types of public goods, natural resources in particular. } \\
\text { Optimization of the offer of socially useful goods (services) }\end{array}$ \\
\hline Using & There is no target funding link & $\begin{array}{l}\text { Targeted use to finance certain government programs. } \\
\text { Distribution of public services through a pricing mechanism that } \\
\text { promotes their rational and efficient use by creating conditions to } \\
\text { restrict access to them for inefficient users on the basis of their } \\
\text { payment, ultimately increasing the economic efficiency of such } \\
\text { services and compensating for externalities (e.g. in case of private } \\
\text { failure) sector for the provision of certain types of public services, } \\
\text { such as environmental protection, law enforcement, copyright } \\
\text { protection, etc.) }\end{array}$ \\
\hline Types & $\begin{array}{l}\text { Direct (taxable income, in- } \\
\text { come, property) and indirect } \\
\text { (markup on sales price: VAT, } \\
\text { excise, duties) }\end{array}$ & $\begin{array}{l}\text { Fees from users or fees for consumed services that benefit the } \\
\text { consumer (lease of property, fees for the use of highways, use of } \\
\text { natural resources, permits and licenses); } \\
\text { Regulatory fees (state duty, court fees, patents for inventions and } \\
\text { copyright registration, attorney's, auditor's licenses, etc., certifi- } \\
\text { cation and standardization of goods (works, services) }\end{array}$ \\
\hline
\end{tabular}




\begin{tabular}{|c|c|c|}
\hline 1 & 2 & 3 \\
\hline $\begin{array}{l}\text { The economic } \\
\text { essence }\end{array}$ & $\begin{array}{l}\text { Ensuring the optimal propor- } \\
\text { tion of distribution of income } \\
\text { (profits), value added and other } \\
\text { monetary characteristics of } \\
\text { economic activity between tax- } \\
\text { payers and the state, sufficient } \\
\text { to maintain the economic feasi- } \\
\text { bility of continuing a certain } \\
\text { type of economic activity and } \\
\text { financial support of state func- } \\
\text { tions at all levels of govern- } \\
\text { ment }\end{array}$ & $\begin{array}{l}\text { Compensation for the cost of marginal costs of production and } \\
\text { sale of certain types of goods (services) that are not produced by } \\
\text { the private sector. Guided by the increase in economic efficiency, } \\
\text { the fee for services may exceed or be lower than the marginal cost } \\
\text { of their production and sale }\end{array}$ \\
\hline Tax Payer & $\begin{array}{l}\text { Persons (legal or natural) who } \\
\text { are obliged to pay taxes, fees } \\
\text { and perform other obligations } \\
\text { related to such payment (for } \\
\text { example, filing a tax return) }\end{array}$ & $\begin{array}{l}\text { The user is defined as an economic agent who is responsible for } \\
\text { reducing the cost, damage, depletion of a particular product (ser- } \\
\text { vice) }\end{array}$ \\
\hline
\end{tabular}

Source: developed by the author on the basis of works [22-23].

In the developed countries of the world there is a tendency to expand the use of environmental taxes. The impact of environmental taxes is due to changes in relative prices for the sale of goods (services), production (extraction), circulation and consumption of which harms the environment. First of all, it is energy (natural gas, oil, coal), as well as the use of other natural resources (subsoil, land, forest, air, etc.).

The state, on the basis of ownership of natural resources and fiscal sovereignty in order to solve environmental problems uses a variety of tools, environmental taxes, among the advantages of which are the lack of need for additional administrative and permitting structures that require additional funding. That is, the admi- nistrative costs of reducing environmental risks are reduced with the simultaneous accumulation of certain amounts of financial resources that can be used to finance environmental measures.

In addition, environmental taxes allow a more accurate assessment of changes in relative prices in the economy and the extent of damage to the environment. Derivatives for their calculation are physical quantities (engine capacity, change in the proportions of the chemical composition of individual elements of the environment, such as the level of $\mathrm{CO} 2$, etc.). The list of basic environmental taxes and their characteristics are presented in Table 3.

List of basic environmental taxes and their characteristics

\begin{tabular}{|l|l|}
\hline \multicolumn{1}{|c|}{ Name } & \multicolumn{1}{c|}{ Characteristic } \\
\hline Pigou's taxes & Taxes with fixed rates set per unit of pollutant emissions or per unit of damage \\
\hline Indirect environmental taxes & $\begin{array}{l}\text { Taxes with ad valorem (as a percentage of value) rates set per unit of pollutant emissions or } \\
\text { per unit of damage }\end{array}$ \\
\hline $\begin{array}{l}\text { Taxes that have an unpredictable } \\
\text { impact on the environment }\end{array}$ & $\begin{array}{l}\text { Excise duties (on cars and fuel), in some cases, special import and export duties) affect the } \\
\text { consumption of "environmentally dirty" products by reducing the consumption of goods } \\
\text { whose production (use) is harmful to the environment }\end{array}$ \\
\hline Target taxes & $\begin{array}{l}\text { Its are installed in order to mobilize additional resources in the state treasury for their further } \\
\text { use in environmental and other measures, environmental in particular }\end{array}$ \\
\hline
\end{tabular}

Source: developed by the author on the basis of works: Vollebergh H. (2012). Environmental taxes and green growth: Exploring possibilities within energy and climate policy, PBL Netherlands Environmental Assessment Agency, The Hague.; Fullerton D., Leicester A. and Smith S. (2010). "Environmental Taxes", in J. Mirrlees etal, (eds.), Dimensions of Tax Design: the Mirrlees Review, Oxford University Press, Available at: www.ifs.org.uk/mirrleesreview/dimensions/ch5.pdf; Hill J., Hislop H. and Bégin A.-E. (2008). Good product, bad product? Making the case for product levies. Green Alliance, February 2008.; Hogg D. et al. (2014). Study on Environmental Fiscal Reform Potential in 12 EU Member States, Final Report to DG Environment of the European Commission, Eunomia Research and Consulting and Aarhus University. Available at: http://ec.europa.eu/environment/integration/green_semester/pdf/EFR-Final\%20Report.pdf; Kaffine D. and O'Reilly P. (2013). What Have We Learned About Extended Producer Responsibility in the Past Decade? A Survey of the Recent EPR Economic Literature, mimeo, 24 May 2013.

The main problem in determining the parameters of environmental taxes is the assessment and measurement (spatial, temporal, physical, in monetary terms, etc.) of environmental damage: air emissions, water bodies, etc., as well as the distribution of the tax burden between producers of products subject to environmental taxation and its consumers. After all, it is difficult to assess the consequences of environmental damage even 
the year after it is caused. At the same time, in the case of the introduction of an additional tax burden on the production, circulation and consumption of certain types of products, producers will try as much as possible to transfer it to consumers in the sale price of manufactured products.

Accumulation of revenues from the collection of environmental taxes and their rational distribution in the system of budgetary regulation creates additional opportunities for the development of environmentally hazardous methods of material production for all types of economic activity. However, at the present stage of development in many countries around the world, in Ukraine, including Environmental taxes do not yet play a significant role in the system of instruments of state regulation, both in terms of incentives and financial support for government environmental programs.

With the adoption of the Tax Code [24] in the field of state regulation of environmental issues in Ukraine there have been positive changes. From January 1, 2011 the fee for environmental pollution has been replaced. The Final Provisions of the Tax Code provide for the authority of the Cabinet of Ministers of Ukraine to annually revise the maximum amount of environmental tax rates taking into account the inflation index [25].

Conclusions. The study allows us to draw the following conclusions:

1. Among the defining conditions of administrative and market regulation of economic processes on the basis of investment and innovation are environmental issues, the leading role in which is given to environmental taxation. The main difficulty in determining the main parameters (list, rates, exclusions) of environmental taxes is the assessment and measurement (spatial, temporal, physical, in monetary terms, etc.) of environmental damage in the form of air emissions, reservoirs, etc., as well as the distribution of tax burden between producer's subject to environmental taxation and its consumers.

2. Based on the results of the analysis of the theory of environmental taxation, the author's scheme of comparing the main characteristics of the tax and the fee for use, including natural resources, is proposed. Among the main differences is that the tax is compulsory, while the usage fee is voluntary. There are also a number of discrepancies between the economic nature of the tax and the usage fee, including the link between certain payments and the financing of government programs, identification of payers, and so on.

3. Among the promising areas of further research in the field of environmental taxation should identify developments aimed at improving the efficiency of state regulation of production and circulation of all excisable goods, motor fuel, motor transport and alcohol in particular, and analyze the feasibility of deeper differentiation of taxation parameters, calculation mechanism tax liabilities (ad valorem, fixed or combined rates, exclusions, etc.), features of the customs regime for excisable products, as well as expanding the list of goods, produc- tion (consumption) of which is subject to excise and environmental taxes.

\section{References}

1. Veklych, O. O. (2016). First results of fiscal decentralization of environmental taxation. Ekonomika Ukrainy-Economy of Ukraine, No. 3, pp. 60-74 [in Ukrainian].

2. Veklych, O. O. (2016). Urgent measures to update the economic and legal mechanism of environmental regulation. Economical Problems of Sustainable Development: Proceedings of the International Scientific and Practical Conference dedicated to the memory of prof. O. F. Balatskii (Vol. 1), (pp. 137-140). Sumy, SumSU [in Ukrainian].

3. Polishchuk, V. G., Zakharchuk, O. M. (2016). Financial securing the steel development of Canada: a message for Ukraine. Economic Forum, 2, pp. 286-294 [in Ukrainian].

4. Polishchuk, V. G. (2016). Foreign dosage of tax incentives for the development of regions as a result of changing the capitalization of the economy of Ukraine. Economic Forum, 4, pp. $92-99$ [in Ukrainian].

5. Gerasimchuk, Z. V., Polishchuk, V. G. (2011). Stimulation of the development of the region: theory, methodology, practice. Lutsk, RVV LNTU. 515 p. [in Ukrainian].

6. Kozarezenko, L. V. (2016). The tax policy of human potential development. Ekonomika ta derzhava, 5, pp. 26-31 [in Ukrainian].

7. Boronos, V. G., Savchenko, K. V. (2008). Budgetary and taxation of the mechanism of management, ecologically directing the innovative development of the economy. Svit finansiv, 4 (17), pp. 175-181 [in Ukrainian].

8. Vakhnovska, N. A., Polishchuk, V. G., Ivanova, I. O. (2016). Financial policy in the context of stimulating environmental protection in Ukraine. Economic Forum, 4, pp. 112-118.

9. Pokataeva, O. V., Tomareva-Patlakhova, V. V. (2016). Practice of state tax policy of ecology in the minds of realizing a new economic development. Economic Bulletin of the Zaporozhye State Engineering Academy, 1, pp. 124-133.

10. Environmental taxes. Retrieved from http://rus-finans.com/osobennosti-nalogooblojeniya-v-stranah-evrope iskogo-soyza / ekologicheskie-nalogi.php.

11. Ekins, P. Theory and Practice of Environmental Taxation. Retrieved from http://www.Greentaxreport. co.uk/read-chapters-online/11-theary-and-practicw-of-environmental-taxation? showall $=1$.

12. Pigou, A. (1985). Economic theory of welfare. Moscow, Progress [in Russian].

13. EaP Green. (2016). Assessing the Green Transformation of the Economy: A Guide for EU Eastern Partnership Countries. Paris. Retrieved from http: //www.green-economies-eap.org/ru/resources/EaP\%20GR EEN_GGI\%20Guide_clean_RUS_Final.pdf.

14. Pleasure for the Association between Ukraine, from one side, and the European Union, the European Sports Industry with the atomic energy and the other member states, from the other side. Retrieved from https://www.kmu.gov.ua/ua/diyalnist/yevropejska-integra ciya/ugoda-pro-asociacyu. 
15. Decree of the President of Ukraine від №392 2020 "About the decision for the sake of national security and defense of Ukraine". Retrieved from https: //www.president.gov.ua/documents/3922020-35037.

16. Law of Ukraine On the ratification of Parisian agreement. Retrieved from https://zakon.rada.gov.ua/laws/ show/1469-19\#Text.

17. Law of Ukraine On the Basic Ambush (Strategy) of the State Ecological Policy of Ukraine for the period up to 2030 from the 28.02.2019, No. 2697-VIII. Retrieved from https://zakon.rada.gov.ua/laws/show/2697-19\#Text.

18. Law of Ukraine dated 25.06.1991 No. 1264-XII "On the protection of the natural environment". Vidomosty Verkhovnoi For Ukraine (VVR), 1991, No. 41, p. 546. Retrieved from https://zakon.rada.gov.ua/laws/show/ 126412\#Text.

19. Mishchenko, V. S. (2016). Meaning the basis of ecological support in Ukraine: methodology and practice. Economics of Ukraine, 3, pp. 75-87.

20. Bublyk, M. I. (2016). Industrial Tax as the New Tool for Regulating Man Made Damage in Environmental Protection Mechanism. Naukoviy Bulletin of NLTU Ukraine, Vol. 26, No. 2, pp. 130-134. doi: https://doi.org/10.15421/40260219.

21. Yarotska, O. V. (2016). Ecological tribute for skipping foreign speech at the water facility in the system of fiscal regulation of water-cooling system of Ukraine. Bulletin of KhNAU. Series: Economics of Science, 2, pp. 382-392.

22. Handbook on Taxation (Public Administration and Public Policy). (1999). Routledge; 1 edition (January 4, 1999). $1008 \mathrm{p}$.

23. Tax Policy Handbook. IMF. (1995) / Parthasarathi Shome (Editor). $335 \mathrm{p}$.

24.Tax Code of Ukraine: 02.12.2010, No. 2755-VI (with changes). Kyiv, Center for Educational Literature. $584 \mathrm{p}$.

25. Ecological tax. Retrieved from http: // biznes.km. ua/onenews/Ekologichnij-podatok.html.

Островецький В. І. Перспективи розвитку системи екологічного оподаткування: консолідація, диференціація, розширення бази оподаткування

У статті на основі аналізу динаміки та структури макроекономічних пропорцій, а також методів державного регулювання ринкових відносин наголошується на необхідності дотримання концепції «зеленого» зростання, в тому числі шляхом розробки та консолідації екологічного оподаткування. Серед ключових векторів діяльності у цьому напрямі пропонується поглиблювати диференціацію параметрів екологічного оподаткування та розширювати базу оподаткування (розширення переліку товарів, виробництво (споживання) яких підлягає екологічному оподаткуванню).

Ключові слова: «зелена» економіка, «зелене» зростання оподаткування, екологія, екологічний податок, акциз.

Ostrovetskyy V. Perspectives for the Development of the Environmental Taxation System: Consolidation, Differentiation, Expansion of the Tax Base

The current economic situation in Ukraine, which is exacerbated by several global issues, such as the political crisis in eastern Ukraine and the spread of COVID-19, requires continuous improvement and development of new environmental instruments to be developed based on balancing state and society as well as preserving the country's natural resource potential for future generations. The system of environmental protection instruments must ensure the efficient functioning of the economic system and not create an excessive burden.

Economic instruments: taxes, licenses, quotas, fees, special permits, are gradually replacing the command-administrative methods of environmental management, the system of which was built based on special subsidies, the use of which justified itself in centralized management of the economy in Soviet times. However, in the conditions of the development of market relations, which are based on the principles of democracy, entrepreneurship, development of various forms of ownership, the system of subsidies proved to be ineffective. To replace it began to develop a system of economic incentives for environmental protection, the main elements of which are accessible to the object of use (license, permit), as well as a special fee, tax, the parameters of which are set depending on the scale of damage (pollution) in absolute values or as a percentage of the cost of production.

Among the main tools for regulating the environmental aspects of industrial production, first of all, are those that regulate the supply and demand for goods (services), the production and sale of which harms consumers and the environment.

Based on the analysis of the dynamics and structure of the main macroeconomic proportions, as well as methods of state regulation of market relations, the article emphasizes the need to adhere to the concept of "green" growth, including through the development and consolidation of environmental taxation. Among the areas of activity in this area, it is proposed to deepen the differentiation of environmental taxation parameters and expand the tax base (expansion of the list of goods, production (consumption) of which is subject to environmental taxation).

Keywords: "green" economy, "green" growth of taxation, ecology, ecological tax, excise tax.

Островецкий В. И. Перспективы развития системы экологического налогообложения: консолидация, дифференциация, расширение базы налогообложения

В статье на основе анализа динамики и структуры макроэкономических пропорций, а также методов государственного регулирования рыночных отношений подчеркивается необходимость соблюдения концепции «зеленого» роста, в том числе путем разработки и консолидации экологического налогообложения. Среди ключевых векторов деятельности в этом направлении предлагается углублять дифференциацию параметров экологического налогообложения и расширять базу (расширение перечня товаров, производство (потребление) которых подлежит экологическому налогообложению).

Ключевые слова: «зеленая» экономика, «зеленый» рост налогообложения, экология, экологический налог, акциз.

Received by the editors: 12.10 .2020 and final form 29.12.2020 